\title{
Study on the Application of the Anti-Japanese War Sites in the Public Course of Ideological and Political Education in Colleges and Universities
}

\author{
Taking the Anti-Japanese War Sites in Yunnan as the Example
}

\author{
Jun Li \\ Chongqing College of Electronic Engineering \\ Chongqing, China 401331
}

\begin{abstract}
The anti-Japanese war in Yunnan is an important part of China's anti-Japanese war. And it has a unique and important position. Since the beginning of the antiJapanese war in western Yunnan, Yunnan became the forefront of the anti-Japanese war. After the war, it has left a lot of relics, ruins and cultural relics. These ruins and cultural relics not only show the historical truth, but also are the evidence to make the distinction between the right history and wrong history, and to determine the historical merits. It is also an important practice teaching base to develop patriotism education and commemorate the anti-war heroes. These ruins and cultural relics are made into pictures, text, video, and voice commentary. And it can organize students to visit the field. Then, the students can write a sense of view, etc. These ways can be applied to the ideological and political courses in reasonable manners. It has a very important practical significance for the students to understand the history of the war, to have the patriotic education, and to promote the AntiJapanese war humanities spirit. The students would work hard to achieve the great rejuvenation of the Chinese nation. It would undoubtedly play a multiplier effect.
\end{abstract}

Keywords-Anti-Japanese War sites; Yunnan; colleges and universities; public courses of ideological and political education; application

\section{INTRODUCTION}

In the Second World War, the anti-Japanese war in China as the world's main battlefield of the anti-fascist war has made a great contribution to the victory of the world antifascist war. The Chinese people have made a great sacrifice. There are a large number of anti-Japanese war sites and antiJapanese war cultural relics in the country. Yunnan, as a gateway to the southwest of the motherland, has a very unique strategic position in the anti-Japanese war. The antiJapanese war in Yunnan also became an important part of the Chinese People's War of Resistance against Japanese aggression. First of all, after the outbreak of the comprehensive resistance against Japanese aggression, Yunnan became the rear area in the anti-Japanese war. It bears the provisions in the anti-Japanese war. Secondly, after the outbreak of the Pacific War, Yunnan has become a common part of China's anti-Japanese battlefield and the world anti-fascist war in the east. In the end, the Japanese army attacked from Myanmar to western Yunnan in May
1942. China began the anti-Japanese war in western Yunnan. Yunnan has become the forefront of the war of resistance against Japan. In this series of changes, Yunnan has made an indelible feat in anti-Japanese war of China. Also, there are a large number of anti-Japanese war sites and anti-Japanese war ruins and anti-war cultural relics. These precious antiJapanese war sites and cultural relics are the historical witness of the great war of resistance. And the persons should remember the history. They should cherish the antiJapanese war heroes. It should develop anti-fascist spirit. It is also the spiritual power to achieve great rejuvenation of China. And it is a precious base to carry out patriotism education for the students in colleges and universities. For example, the anti-Japanese war sites and cultural relics should be introduced in ideological and political education course of colleges and universities in the appropriate ways. It can attain the result with half effort for students to carry out patriotism education.

\section{DO NOT FORGET HISTORY - THE APPLICATION OF ANTI-JAPANESE WAR RUINS AND CULTURAL RELICS IN OUTLINE COURSE}

President Xi Jinping has made it clear that it is necessary to strengthen the protection and development of the antiJapanese war ruins. And it should play the role of various anti-Japanese war memorial facilities, and provide bases for carrying out anti-Japanese war research, demonstrating the results of the war and carrying out patriotism education. [1] In the Anti-Japanese War of the Chinese nation, the sixth chapter of Outline of Chinese Modern History, the antiJapanese war ruins and cultural relics can be introduced into the classroom of the colleges and universities. As a specific and vivid teaching case, the students can understand the war of resistance and learn the spirit of the war of resistance against Japan. Then, it can develop the patriotism education. During the anti-Japanese war in Yunnan, 13 million peoples of all ethnic groups in Yunnan went to extremely dangerous areas, and repaid the country with supreme loyalty. Literati were not greedy, and the soldiers weren't afraid of death Military and civilian encouraged each other. The young and old, and the people of all nationalities shared a bitter hatred of the enemy. They united as one in anti-Japanese war. In the 
end, they made the victory. During the war, Yunnan had collected more than 4 million soldiers and manpower. In the province of Yunnan, at the time of the population of 13 million, there were one third of the people directly involving in the war of resistance. With the words, it was called "one third of the people joined the army". The Yunnan army and the people had made a great contribution and sacrifice for the war. ${ }^{1}$ In Tengchong warfare in 1944, Tengchong mobilized more than 46,000 migrant workers to transport ammunition for food, and to repair highway bridges in anti-Japanese war when the wizard, the wounded, engages in reconnaissance. They rescued for wounded in groups, and made investigation and guidance. Young people went to fight for the war, the old and weak women and children weren't idle. They transported 60 million army provisions from Hupa in Baoshan. The task is performed. It took only less than 6 days. With the deficiency of the supply, the local people would rather not eat or eat less. They would cook the food, and braved the hail of bullets to the front. As the Chinese expeditionary army commander Wei Lihuang said that the victory of the counterattack in Tengchong was the soldiers' efforts to destroy the bandits, and Tengchong people's support to the war. [2] And the oil pipeline ruins in west Yunnan was the warfare lifeline of the allied war. This oil pipeline was built by the US, Burmese, India, China and other countries. It was $3218 \mathrm{~km}$ of oil pipeline, was China's first refined oil pipeline, and was also the world's longest refined oil pipeline for the victory of the Chinese war. It provided protection for the victory of anti-Japanese war. Along the long lines of more than 300 kilometers, the engineers, the workers and labors were from China, the United States, Burma, India and other countries. They did it by hand and carried it on one's shoulders. With 2 million man-hours, they completed the oil pipeline in one and a half years from India, Calcutta, Myanmar to Kunming. It was completed 6 days ahead of schedule. The completion of this tubing provided fuel services for aircraft, tanks and field units, as well as trucks for road engineers. Yunnan people had also made a great contribution to build the oil pipeline.

During the war, Yunnan ethnic minorities were also active. The ethnic minority chieftains established more than 10 anti-Japanese guerrillas along Yunnan's thousands of miles of border, such as Wanshan, western Yunnan, southwestern of Yunnan, southern of Yunnan. The number was more than 5,000 people. With the leadership of the chieftains, Washan compatriots in the country held a grand anti-Japanese vow with drinking chicken blood wine. And they solemnly vowed that to protect the Washan, to swear to kill the thief was necessary. They would never go back with the landscape as evidence. The chieftains of Meng Teng, Hanxian responded to Li Genyuan, the supervision of the Yunnan and Guizhou. He said that the Japanese invaded us, and the people who are nationals angered. Wanxian had defensive responsibility to kill the enemy insult. [2] It was clear that the people of all ethnic groups in Yunnan united

${ }^{1}$ It was selected from p47, p51, p52, p54, p97, p103, p207 in the article 8 and article 47 of Yunnan cultural and historical materials. It was edited by the Yunnan provincial committee of literature and history committee of the Chinese people's political consultative conference in February 1st edition, 1995. together with the common hatred to fight against the national crisis. And they had undaunted spirit to defend the territory and all criminals in the end of the war. During the war of resistance against Japan, there were more than 20 ethnic minority people directly joining the war of resistance against Japan. It had become the most distinctive part of antiJapanese war in the western Yunnan. Also, a number of awkward anti-Japanese heroes appeared. For example, Zhang Chong, the anti-Japanese star six of Yi, Duan Hao, the chieftain of Liuku, anti-Japanese hero, Xian Guangtian, the chieftain of Dai, an anti-Japanese hero, Zhang Gongda, antiJapanese general, Su Zhixian, anti-Japanese hero of Yi, and so on. With the help of the nationalist forces in Yunnan, the anti-Japanese guerrillas of ethnic minorities actively enlisted weapons and ammunition, engaged military instructors, and trained anti-Japanese guerrilla warfare. And then, they beat the Japanese invaders heavily. Their cohesion with the communist coexistence and the spirit of patriotism not only wrote a magnificent chapter in the history of the war in Yunnan, but also made the example for the next generation to learn.

The memorial hall of anti-Japanese war was the key cultural facilities construction project in Yunnan Province. For example, the anti-Japanese war memorial hall in the west of Yunnan, anti-Japanese war memorial hall in Longling, the hump route memorial hall in $\mathrm{Nu}$ river, the leader of the second army, Zhou Baozhong general memorial hall, national war cemetery in Tengchong, and temples in Jiangchuan (Huai Yuan). All of these things are important anti-Japanese cultural heritage. These memorials not only reproduce the hardships and tragedy of the war, but also reproduce the Chinese soldiers' patriotic spirits and desperate sacrifice. The third army commander of national revolutionary army, Tang Huaiyuan said before his death: "There are only dead army chief, and no captive army chief in China." In the event of exhaustion and failure to break through, he made a suicide with the bombs and left notes. It was said that "After I died, I hope the commander-in-chief and chief of staff to clean up the mess and to continue fighting against the war. And then I would have no pity." [2] On January 4, 1942, it had published the memorial essay of the loyalty to mourn the Tang Huaiyuan and the soldiers who were dead in the battle of the Zhongtiao Mountain. In this essay, it was said that senior generals could make examples for the soldiers, and few generals could make suicide to avoid to be captured. In fact, the death of the general Tang was the supreme loss of the country. The general fought for the cities of the country. And he was the pillars of the war. The country lost this important city. And the pillar was lost in this war. It would increase the difficulties to win antiJapanese war. Considering this situation, it was a pity. ${ }^{2}$ The death of Tang Huaiyuan had made a tragedy in the history of anti-Japanese war.

Besides, there is memorial tower to commemorate the 198 army group attacking Tengchong. ${ }^{3}$ There is China

\footnotetext{
${ }^{2}$ The author of Mourning Mercy was unknown. And it was published in the first edition of Yunnan Daily in January 4, 1942.

${ }^{3}$ The martyrs of Chinese air force in the war of resistance against Japan buried in Kunming.
} 
expeditionary cemetery in March Street in Dali. They were 261 China expeditionary forces and sick soldiers' cemetery, and so on. For example, the note on the China air force cemetery was said that these anti-Japanese heroes were buried in the mountains of Yunnan. The national moral courage is great. Past experience, if not forgotten, is a guide for the future. These cemeteries, monuments, memorials and cultural relics are important practice teaching bases to memory the martyrs and develop the patriotism education. These anti-war sites and relics could be made into video and voice interpretation. And it could organize college students to watch these videos. It could get twofold results with half the effort. Students could understand the history of the war, and didn't forget humiliation. Then they would work hard, and carry forward the spirit of war.

\section{AN IN-DEPTH UNDERSTANDING OF THE NATIONAL CONDITIONS - THE APPLICATION OF ANTI - JAPANESE WAR Sites AND CUltural RELICS IN SUMMARY OF MAO ZEDONG'S THEORIES}

On the Protracted War was written by Mao Zedong. He pointed that anti-Japanese war was a protracted war, and the final victory of the war must belong to China. At that time, the base of anti-Japanese war in China was weak. Both the economy and military couldn't compete with Japan. However, the Chinese wouldn't be slaves. And they were unwilling to be teased. Even the Japanese had harried the northern areas along Yellow River. Even the Japanese had harried the areas along Yangtze River. Even the Japanese had made vertical fire in Changsha. Also, the Japanese had made the Nanjing massacre. Forty million Chinese could be united as one and be concentrating their efforts to fight for anti-Japanese war. They would rather fight than escape from the areas. They had left their lives. They belong to the country. On the battle line, they were hungry. In the five months, they had no food. Similarly, they could defeat the enemy. ${ }^{4}$ This strong anti-war will and high resistance to the war made the Chinese people and civilians unite as one wholeheartedly. And soon, they broke the Japanese dream to occupy China in the short term. And then, the war was into the difficult long-term strategic stalemate. And it entered in the strategic counterattack stage. And China's real strategic counterattack is from the western Yunnan and the northern Burma. The Chinese army invested a total of 21 US Kikaika Gunta-Mech Platoon. The Chinese troops stationed in India entered into Burma from India. And they combat the enemy from west to east. China expeditionary army crossed the Nu River, and attacked from east to west. The two armies made the attack from the different directions. And this war had kept for 15 months, nearly $2400 \mathrm{~km}$. It completely defeated the Japanese 33rd army. It had wiped out the Japanese elite 18th division and the first evil of Nanjing Massacre culprit, the 56th division, the eradication of the 55th division, the second division of the main force and the 49th division. In the end, they had expelled the enemy from the western Yunnan. The Chinese army also suffered heavy casualties. In Tengchong campaign, the china expeditionary army had 1234 officers injured, and 17075 soldiers injured. Yunnan anti-Japanese war sites not only expressed the war in western Yunnan and northern Burma North. And it had undertaken the tragedy history of anti-Japanese war. It was major historical event to carry the Chinese people fight against foreign aggression and to strive for national independence and liberation. Also, it was the evidence to reveal the truth of history, to distinguish the truth among the history, to determine the historical merits. 70 years later, flames of war has disappeared. However, it had left a large number of anti-Japanese monument groups in Shidian. These defensive work fortifications were important historical merits to demonstrate the confrontation between China expeditionary force and Japanese army. It showed the details in "Table I":

${ }^{4}$ In May, 21, 1944. 
TABLE I. DEFENSIVE WORK FORTIFICATIONS

\begin{tabular}{|c|c|c|c|c|c|}
\hline $\begin{array}{c}\text { Serial } \\
\text { Number }\end{array}$ & Name & Location & Specification & $\begin{array}{c}\text { Construction } \\
\text { Institution } \\
\end{array}$ & The Influences \\
\hline 1 & $\begin{array}{l}\text { Wang } \\
\text { jiangtai } \\
\text { pillbox }\end{array}$ & $\begin{array}{l}\text { Dapingzi } \\
\text { Village in } \\
\text { Taiping }\end{array}$ & $\begin{array}{l}\text { It was steel. And it was irregular hexagonal structure. The height } \\
\text { was } 2.04 \text { meters. The hexagonal length was } 1.2-1.8 \text { meters. The } \\
\text { width was } 0.75 \text { meters. The inner height was } 1.64 \text { meters, and the } \\
\text { height of shooting holes was } 0.3-0.4 \text { meters. The width was } 0.21 \\
\text { meters, and the wall thickness was } 0.41 \text { meters. }\end{array}$ & $\begin{array}{l}71 \text { defensive } \\
\text { works forces } \\
\text { of China } \\
\text { expeditionary } \\
\text { army }\end{array}$ & $\begin{array}{l}\text { It could control the } \\
\text { Burma road and } 20 \\
\text { kilometers across the } \\
\text { surface of the } \\
\text { Huitong river. }\end{array}$ \\
\hline 2 & $\begin{array}{l}\text { Three } \\
\text { mountain } \\
\text { pillbox }\end{array}$ & $\begin{array}{l}\text { Dapingzi } \\
\text { Village in } \\
\text { Taiping }\end{array}$ & $\begin{array}{l}\text { It was steel. And it was irregular hexagonal structure. The length } \\
\text { was } 1.4-1.08 \text { meters. The width was } 0.65 \text { meters. The height of } \\
\text { entrance was } 1.8 \text { meters. The height of shooting holes was } 0.37 \text { - } \\
0.65 \text { meters. The width was } 0.3 \text { meters. And the wall thickness } \\
\text { was } 0.4 \text { meters. }\end{array}$ & $\begin{array}{l}\text { It was the } \\
\text { same to the } \\
\text { above. }\end{array}$ & $\begin{array}{l}\text { It could control the } \\
\text { surface of the old } \\
\text { ferry and } 10 \\
\text { kilometers across the } \\
\text { road in the west of } \\
\text { the river. }\end{array}$ \\
\hline 3 & $\begin{array}{l}\text { The big } \\
\text { mountain } \\
\text { group } \\
\text { pillbox }\end{array}$ & $\begin{array}{l}\text { Xia Ba } \\
\text { Village in } \\
\text { Taiping in } \\
\text { Lu Jia } \\
\text { mountain }\end{array}$ & $\begin{array}{l}\text { It was steel. And it was irregular hexagonal structure. The } \\
\text { common height was } 2.2 \text { meters. The width was } 0.85 \text { meters. The } \\
\text { inner height was } 1.7 \text { meters. The height of shooting holes was } 0.4 \\
\text { meters. The width was } 0.5 \text { meters. And the wall thickness was } \\
0.4 \text { meters. }\end{array}$ & $\begin{array}{l}\text { It was the } \\
\text { same to the } \\
\text { above. }\end{array}$ & $\begin{array}{l}\text { It could control } 10 \\
\text { kilometers from the } \\
\text { old ferry to the } \\
\text { surface of Nu river. }\end{array}$ \\
\hline 4 & $\begin{array}{l}\text { Jin } \\
\text { Gangyuan } \\
\text { Pillbox }\end{array}$ & $\begin{array}{lr}\text { Wu } & \text { Mu in } \\
\text { Tai } & \text { Ping } \\
\text { town } & \end{array}$ & $\begin{array}{l}\text { It was steel. And it was irregular hexagonal structure. The } \\
\text { common height was } 1.8 \text { meters. The length was } 1-1.8 \text { meters. } \\
\text { The width was } 0.85 \text { meters. The height of shooting holes was } \\
0.25-0.3 \text { meters. The width was } 0.21-0.65 \text { meters. The wall } \\
\text { thickness was } 0.4 \text { meters. }\end{array}$ & $\begin{array}{l}\text { It was the } \\
\text { same to the } \\
\text { above. }\end{array}$ & $\begin{array}{l}\text { It could control } 10 \\
\text { kilometers across the } \\
\text { downstream of } \\
\text { Huitong bridge. And } \\
\text { it was in the surface } \\
\text { of Nu river. }\end{array}$ \\
\hline 5 & $\begin{array}{ll}\mathrm{Wu} & \mathrm{Mu} \\
\text { Pillbox } & \end{array}$ & $\begin{array}{lr}\text { Wu } & \text { Mu in } \\
\text { Tai } & \text { Ping } \\
\text { town } & \end{array}$ & $\begin{array}{l}\text { It was steel. And it was irregular hexagonal structure. The } \\
\text { common height was } 2.2 \text { meters. The length was } 1.2-2.4 \text { meters. } \\
\text { The width was } 0.85 \text { meters. The height of shooting holes was } \\
0.25 \text { meters. The width was } 0.65 \text { meters. And the wall thickness } \\
\text { was } 0.45 \text { meters. }\end{array}$ & $\begin{array}{l}\text { It was the } \\
\text { same to the } \\
\text { above. }\end{array}$ & $\begin{array}{l}\text { It could control } 20 \\
\text { kiolmeters across the } \\
\text { surface of Nu river } \\
\text { from the downstream } \\
\text { of Huitong bridge to } \\
\text { Pan zhihua ferry. }\end{array}$ \\
\hline 6 & $\begin{array}{l}\mathrm{Yu} \text { Tang } \\
\text { Mountain } \\
\text { Pillbox }\end{array}$ & $\begin{array}{l}\text { Dong Bang } \\
\text { village in } \\
\text { Tai Ping }\end{array}$ & $\begin{array}{l}\text { It was steel. And it was irregular rectangle structure. The length } \\
\text { was } 3.4 \text { meters. The width was } 3.4 \text { meters. The height of } \\
\text { shooting holes was } 0.6 \text { meters. And the wall thickness was } 0.6 \\
\text { meters. }\end{array}$ & $\begin{array}{l}\text { It was the } \\
\text { same to the } \\
\text { above. }\end{array}$ & $\begin{array}{l}\text { It could control over } \\
10 \text { kilometers across } \\
\text { the surface of } \mathrm{Nu} \\
\text { river in the } \\
\text { downstream of Mang } \\
\text { Hai bridge in Lu } \\
\text { river. }\end{array}$ \\
\hline 7 & $\begin{array}{l}\text { Two Slope } \\
\text { Pillbox }\end{array}$ & $\begin{array}{l}\text { Pan Zhihua } \\
\text { in Wang Jia } \\
\text { village in } \\
\text { He Yuan }\end{array}$ & $\begin{array}{l}\text { It was steel. The length was } 4.5 \text { meters. The width was } 4.5 \\
\text { meters. The depth was } 1.5 \text { meters. }\end{array}$ & $\begin{array}{l}\text { It was the } \\
\text { same to the } \\
\text { above. }\end{array}$ & $\begin{array}{l}\text { It could control over } \\
10 \text { kilometers across } \\
\text { the surface of } \mathrm{Nu} \\
\text { river in the stream of } \\
\text { Pan Zhihua ferry. }\end{array}$ \\
\hline 8 & $\begin{array}{l}\text { Hong } \\
\text { Liangzi } \\
\text { Pillbox }\end{array}$ & $\begin{array}{ll}\text { Sha } & \mathrm{Zi} \\
\text { village } & \text { in } \\
\text { Jiu Fang } & \end{array}$ & $\begin{array}{l}\text { It was steel. It was irregular Long square hexagon. The common } \\
\text { height was } 2 \text { meters. The length was } 1.2-1.8 \text { meters. The width } \\
\text { was } 0.85 \text { meters. The height of shooting holes was } 0.3 \text { meters. } \\
\text { The width was } 0.21 \text { meters. The wall thickness was } 0.42 \text { meters. }\end{array}$ & $\begin{array}{l}\text { It was the } \\
\text { same to the } \\
\text { above. }\end{array}$ & $\begin{array}{l}\text { It could control over } \\
10 \text { kilometers across } \\
\text { the surface of } \mathrm{Nu} \\
\text { river in the stream of } \\
\text { the black ferry. }\end{array}$ \\
\hline 9 & $\begin{array}{l}\text { The old } \\
\text { soldier hole } \\
\text { pillbox }\end{array}$ & $\begin{array}{l}\text { Ma an } \\
\text { mountain in } \\
\text { Sha Zi in } \\
\text { Jiu Fang }\end{array}$ & $\begin{array}{l}\text { It was steel. It was irregular Long square hexagon. The height } \\
\text { was } 1.8 \text { meters. The length was } 1.2-1.8 \text { meters. The width was } \\
0.85 \text { meters. The height of shooting holes was } 0.3 \text { meters. And } \\
\text { the width was } 0.21 \text { meters. The wall thickness was } 0.45 \text { meters. }\end{array}$ & $\begin{array}{l}\text { It was the } \\
\text { same to the } \\
\text { above. }\end{array}$ & $\begin{array}{l}\text { It could control } \\
\text { kilometers across the } \\
\text { surface of } \mathrm{Nu} \text { river } \\
\text { along the stream of } \\
\text { the black ferry. }\end{array}$ \\
\hline 10 & $\begin{array}{l}\text { Chicken } \\
\text { intestine } \\
\text { pillbox } \\
\text { group }\end{array}$ & $\begin{array}{l}\text { The small } \\
\text { hemp plant } \\
\text { in chicken } \\
\text { intestine in } \\
\text { Jiu Fang }\end{array}$ & $\begin{array}{l}\text { One was steel structure. The eight structures were civil } \\
\text { engineering structures. The length was } 1.5 \text { meters. The width was } \\
1.3 \text { meters. And the depth was } 1-1.8 \text { meters. }\end{array}$ & $\begin{array}{l}87 \text { division } \\
259 \text { regiment } \\
\text { in } 71 \text { army of } \\
\text { China } \\
\text { expeditionary } \\
\text { army }\end{array}$ & $\begin{array}{l}\text { It could control } \\
\text { kilometers along the } \\
\text { black ferry in Jiu } \\
\text { Fang. }\end{array}$ \\
\hline 11 & $\begin{array}{l}\text { Rock head } \\
\text { pillbox }\end{array}$ & $\begin{array}{l}\text { Jiu Fang } \\
\text { village in } \\
\text { Jiu Fang }\end{array}$ & $\begin{array}{l}\text { It was steel. It was irregular rectangle. The length was } 2.3 \text { meters. } \\
\text { The width was } 1.8 \text { meters. The depth was } 1.62 \text { meters. The wall } \\
\text { thickness was } 0.4 \text { meters. }\end{array}$ & $\begin{array}{l}\text { It was the } \\
\text { same to the } \\
\text { above. }\end{array}$ & $\begin{array}{l}\text { It was the same to the } \\
\text { above. }\end{array}$ \\
\hline 12 & $\begin{array}{l}\text { Yang Jia } \\
\text { mountain } \\
\text { pillbox } \\
\text { group }\end{array}$ & $\begin{array}{l}\text { Fu Yang } \\
\text { village in } \\
\text { Yao Guan }\end{array}$ & $\begin{array}{l}\text { The two were steel structures. The other two were civil } \\
\text { engineering structures. The length was } 3.8 \text { meters. The width was } \\
3.5 \text { meters. The height was } 1.3 \text { meters. The wall thickness was } \\
0.6 \text { meters. }\end{array}$ & $\begin{array}{l}\text { It was the } \\
\text { same to the } \\
\text { above. }\end{array}$ & $\begin{array}{l}\text { It could control Wan } \\
\text { Dian and the old city. } \\
\text { And then, it entered } \\
\text { into the tail of the } \\
\text { river. }\end{array}$ \\
\hline
\end{tabular}

${ }^{\text {a. }}$ The source was cleared up according to defensive works remains in anti-Japanese war in Shidian. 
In May 1942, the Japanese invaders occupied large tracts of land in west of $\mathrm{Nu}$ river along the Burma Road. Under the Japanese army, the Baoshan government was not afraid of rape. They decided to organize the progressed teachers and traveled students to compose the Baoshan war propaganda team. In Baoshan (including Shidian), there were a lot of
anti-Japanese slogans and posters on the wall in the territory. It aroused the people's national determination to defend the country with solidarity. There were 13 anti-Japanese slogans, one anti-Japanese poster. There were 14 slogans. It showed the details in "Table II" (The illegible words couldn't be list in this table):

TABLE II. 14 SLOGANS

\begin{tabular}{|c|c|c|c|c|}
\hline $\begin{array}{c}\text { Serial } \\
\text { Number }\end{array}$ & Slogan Name & Address & Content & Text Fonts \\
\hline 1 & $\begin{array}{l}\text { Anti-Japanese slogan in } \\
\text { Guanyin Temple }\end{array}$ & $\begin{array}{l}\text { The first group of Bailong water } \\
\text { natural village of Sha ba village } \\
\text { committee of Xunyang town }\end{array}$ & $\begin{array}{l}\text { "To recovery lost ground with the } \\
\text { blood, it would defeat national crisis; } \\
\text { It cooperated with absolute sincerity } \\
\text { to protect the country with the life." }\end{array}$ & $\begin{array}{l}\text { Each word was } 20-40 \\
\mathrm{~cm} \text { square in different } \\
\text { sizes. }\end{array}$ \\
\hline 2 & $\begin{array}{l}\text { Anti-Japanese slogan on } \\
\text { the wall of } \mathrm{Wu} \text { Zhenghe }\end{array}$ & $\begin{array}{l}\text { The second group of Bailong water } \\
\text { natural village of Sha ba village } \\
\text { committee of Xunyang town }\end{array}$ & $\begin{array}{l}\text { "To unity as one to defeat humiliation } \\
\text { and shame" }\end{array}$ & $\begin{array}{l}\text { In } 30 \mathrm{~cm} \text { square, It } \\
\text { inscribed } 8 \mathrm{~cm} \text { square in } \\
\text { small print }\end{array}$ \\
\hline 3 & $\begin{array}{l}\text { Anti-Japanese slogan in } \\
\text { Longxi Temple }\end{array}$ & $\begin{array}{l}\text { Longxi Temple in Longjia Village of } \\
\text { Reshuitang committee }\end{array}$ & $\begin{array}{l}\text { "To unity as one to defeat } \\
\text { humiliation", "To revive the nation", } \\
\text { "To cooperate with absolute } \\
\text { sincerity", "To defeat national } \\
\text { humiliation", "The final victory" }\end{array}$ & \\
\hline 4 & $\begin{array}{l}\text { Anti- Japanese slogan on } \\
\text { Li Xinghan wall }\end{array}$ & $\begin{array}{l}\text { The second group of Longjia village } \\
\text { of Reshuitang village committee in } \\
\text { Renhe }\end{array}$ & "To restore the lost territories" & $\begin{array}{l}\text { Each word was } 80 \mathrm{~cm} \\
\text { square }\end{array}$ \\
\hline 5 & $\begin{array}{l}\text { Anti- Japanese slogan on } \\
\text { the wall of Liu Qi }\end{array}$ & $\begin{array}{l}\text { The third group of Bao Chang } \\
\text { committee of Ren He }\end{array}$ & "To restore the lost territories" & $\begin{array}{l}\text { Each word was } 30 \mathrm{~cm} \\
\text { square }\end{array}$ \\
\hline 6 & $\begin{array}{l}\text { Anti-Japanese slogan in } \\
\text { Bao Chang fortune } \\
\text { temple }\end{array}$ & $\begin{array}{l}\text { The old street of Bao Chang } \\
\text { committee of Ren He }\end{array}$ & $\begin{array}{l}\text { "Efforts to produce in wartime, and } \\
\text { enhance the strength of the war" }\end{array}$ & $\begin{array}{l}\text { Each word was } 20 \mathrm{~cm} \\
\text { square }\end{array}$ \\
\hline 7 & $\begin{array}{l}\text { Anti-Japanese slogan in } \\
\text { Guanyin temple in } \\
\text { Shidian }\end{array}$ & $\begin{array}{l}\text { Guanyin temple, in the south of } \\
\text { Guanyin Natural Village of Shaba } \\
\text { Village Committee of Dianyang }\end{array}$ & $\begin{array}{l}\text { "To unity as one to defeat humiliation } \\
\text { and shame", "The war of resistance } \\
\text { was the only way to fight for the } \\
\text { survival of Chinese nation" }\end{array}$ & $\begin{array}{l}\text { Each word was } 30 \mathrm{~cm} \\
\text { square }\end{array}$ \\
\hline 8 & $\begin{array}{l}\text { Anti- Japanese slogan on } \\
\text { the wall of Yang } \\
\text { Shaowen }\end{array}$ & $\begin{array}{l}\text { The forth group of Bao Chang street } \\
\text { of Bao Chang committee of Ren He }\end{array}$ & $\begin{array}{l}\text { "To tighten one's belt was the } \\
\text { responsibility of the rear people" }\end{array}$ & $\begin{array}{l}\text { Each word was } 20 \mathrm{~cm} \\
\text { square }\end{array}$ \\
\hline 9 & $\begin{array}{l}\text { Anti-Japanese slogan on } \\
\text { the wall of Fan Youxue }\end{array}$ & $\begin{array}{l}\text { The first group of Yang Meizhai } \\
\text { village committee of Yao Guan }\end{array}$ & $\begin{array}{l}\text { "To Raise head, straighten chest, put } \\
\text { up the backbone, set the heel" }\end{array}$ & $\begin{array}{l}\text { Each word was } 60 \mathrm{~cm} \\
\text { square }\end{array}$ \\
\hline
\end{tabular}

For example, these slogans were made into the table. And it was attached to real pictures. Students could understand the quintessence of Mao zedong's thought of protracted war. And they could also understand the words in an introduction to Mao Zedong thought and the theoretical system of socialism with Chinese characteristics. China was a war-torn developing country. The revolution and construction must be from China's national conditions. It should seek truth from facts. China's socialism was still in the early stage, and the socialist construction had long way to go. It should stimulate its strong patriotic feelings, and work hard. They would grow into useful talents for the national community for the rise of China.

\section{TO EVOKE THE PATRIOTISM-THE APPLICATION OF WAR SITES AND CULTURAL RELICS IN THOUGHT MORALS TUTELAGE AND LEGAL FOUNDATION}

The ancients had said: "Everyone should be responsible for the rise and fall of the world". The contemporary college students are parts of the 1.3 billion people. In the chapter two of the inheritance of patriotic tradition and the spirit of China in public class of ideological and moral cultivation and legal basis, it should require college students to inherit the patriotic tradition and to carry forward the patriotism. And it b. The source was fixed according to anti-Japanese slogan group in Shidian. should require the students to be loyal patriots. The students should consciously safeguard the national interests, promote national unity, safeguard the reunification of the motherland, and enhance the national defense concept and national security awareness. To carry out this chapter of the teaching, it could introduce various relevant information on anti-war sites and ruins and cultural relics in Yunnan. And then, the students would really be aware of flesh and blood between the people and the country. In the wartime, Peking University, Tsinghua University and Nankai University were forced to move to Changsha, and then moved to Yunnan. The distance was 1750 kilometers. It has taken 68 days. In the face of the enemy, the death and the displacement, teachers and students should remember the school song "To defeat the thousands of shame, and to recovery the Chinese nation with the talents." They should always cultivate morality and look forward to make contribution to the motherland. In anti-Japanese war, the graduates of union university were more than 3,800 people. Many of them became the backbone of various fields and well-known scholars. The teachers and students in southwest associated university were to save the country with knowledge. They made the immortal monument of the country's spirit, patriotism and nationalism. And they became models for contemporary college students. In 1942, the Japanese 
invaded western Yunnan. Li Genyuan, the supervision of Yungui advocated and adhered to establish the line of defense along the $\mathrm{Nu}$ River. He opposed against the back, and called Chiang Kai-shek, and wanted to fight against the enemy in the front line of the war. And then, he published the famous note to the people in the west of Yunnan. He was 63 years old. Also, he was sick. Then, he went to the front of the war of resistance against Japan. He called for the people in the west of Yunnan to defeat Japanese enemy with collaboration. They wanted to expel the enemy to withdraw from Tengchong, Longling. In the end, the Japanese should be out of the border of Yunnan. Even, the Japanese could be out of the Burma.He said that if he could be conducive to the country and the war of resistance, he would make anything to save the country in the difficult conditions. And he had written a tragedy in the history of anti-Japanese war. [3] And the people were inspired by this note. They went to the front line of anti-Japanese war. Zhang Wende, the retired head of Tengchong, had made a note to Tiandao. And it made the Japanese frustrated.

\section{CONCLUSION}

It was the spirit of the war of resistance against the Chinese nation. "To save the country, to prevent from ruining the house" had made the final victory of antiJapanese war. This was the first complete victory for China to fight against foreign aggression in modern times. $\mathrm{Xi}$ Jinping pointed out that this great victory completely smashed the Japanese militarism conspiracy. And it washed national shame of anti-Japanese war in the modern times. This great victory re-established the status of China in the world. And then, the Chinese people won the respect of the world. This great victory opened up a great prospect of the great rejuvenation of the Chinese nation, and opened a new journey of rebirth for the ancient Chinese. [1] In the teaching, it could made the anti-Japanese war commemorative facilities, sites, cultural relics into text, pictures, video, voice interpretation and other forms to display to the students. Also, it could use teaching practice activities, organize students to visit the practical sites, and write down the sense. It is also an important means to strengthen students' patriotism education.

\section{REFERENCES}

[1] Xi Jinping, Speech at the 70th anniversary of the victory of the Chinese people's anti-Japanese war and the world anti-Fascist war, published by the central party history research office, September 3, 2015.

[2] Liu Yun, Silent feelings-The album of anti-Japanese war sites in Yunnan. People's Publishing House, 2015, p54, p134, p121.

[3] Li Genyuan, the note to the people in the western of Yunnan. Liu Yun, Silent feelings-The album of anti-Japanese war sites in Yunnan. People's Publishing House, 2015, p173. 